\title{
Pengaruh Model Pembelajaran Kooperatif Tipe Team Game Tournament (TGT) Terhadap Keaktifan dan Hasil Belajar Pekerjaan Dasar Otomotif Siswa Kelas X TKRO SMK Negeri 1 Denpasar
}

\section{The Effect of Cooperative Learning Model Type Team Game Tournament (TGT) on the Activity and Learning Outcomes of Automotive Basic Work Class X TKRO Students of SMK Negeri 1 Denpasar}

\author{
I K Adi Suandika1, I N Pasek Nugraha', L J Erawati Dewi1 \\ Universitas Pendidikan Ganesha, Singaraja, Indonesia \\ e-mail: adysuandika88@gmail.com, paseknugraha@undiksha.ac.id, \\ joni.erawati@undiksha.ac.id
}

\begin{abstract}
Abstrak
Penelitian ini bertujuan untuk mengetahui (1) perbedaan keaktifan belajar pekerjaan dasar otomotif antara kelompok siswa yang mengikuti model pembelajaran kooperatif tipe Team Game Tournament (TGT) dengan kelompok siswa yang mengikuti model pembelajaran konvensional (2) perbedaan hasil belajar pekerjaan dasar otomotif antara kelompok siswa yang mengikuti model pembelajaran kooperatif tipe Team Game Tournament (TGT) dengan kelompok siswa yang mengikuti model pembelajaran konvensional (3) perbedaan keaktifan dan hasil belajar pekerjaan dasar otomotif secara simultan antara kelompok siswa yang mengikuti model pembelajaran kooperatif tipe Team Game Tournament (TGT) dengan kelompok siswa yang mengikuti model pembelajaran konvensional. Penelitian ini menggunakan rancangan penelitian deskriptif kuantitatif pada mata pelajaran pekerjaan dasar otomotif, siswa kelas X TKRO di SMK Negeri 1 Denpasar. Objek penelitian ini adalah pelaksanaan, keaktifan dan hasil belajar siswa terhadap model pembelajaran kooperatif tipe Team Game Tournament (TGT). Data dikumpulkan dengan metode observasi, dokumentasi, angket dan tes. Sampel penelitian ini menggunakan teknik random sampling. Data yang diperoleh dianalisis secara statistik dengan MANOVA. Adapun hasil dari penelitian ini adalah (1) rata-rata keaktifan belajar siswa pada kelas eksperimen $(82,25)$, pada kelompok kontrol $(73,28)(2)$ rata-rata hasil belajar siswa pada kelas eksperimen $(76,81)$, pada kelompok kontrol $(63,47)$.
\end{abstract}

Kata kunci: TGT, Keaktifan Belajar, Hasil Belajar.

\section{Abstract}

This study aims to determine (1) the differences in the activity of learning automotive basic work between group students who take the Team Game Tournament (TGT) cooperative learning model and group students who take conventional learning models (2) the differences in learning outcomes of automotive basic work between group students who take the learning model Team Game Tournament (TGT) cooperative type with group students who follow the 
conventional learning model (3) the difference in the activity and learning outcomes of automotive basic work simultaneously between group students who take the Team Game Tournament (TGT) cooperative learning model and group students who follow the conventional learning model. This study uses a quantitative descriptive research design on automotive basic work subjects, class X TKRO students at SMK Negeri 1 Denpasar. The object of this research is the implementation, activeness and learning outcomes of students towards the type of Team Game Tournament (TGT) cooperative learning model. Data were collected by observation, documentation, questionnaire and test methods. The sample of this study used a random sampling technique. The data obtained were analyzed statistically with MANOVA. The results of this study are (1) the average learning activeness of students in the experimental class (82.25), in the control group (73.28) (2) the average student learning outcomes in the experimental class (76.81), in the control group (63.47).

\section{Keywords : TGT, Learning Activeness, Learning Outcomes .}

\section{PENDAHULUAN}

Pendidikan di Sekolah Menengah Kejuruan adalah pendidikan pada jenjang menengah yaitu mengutamakan kemampuan siswa untuk mempunyai kemampuan tertentu. Pendidikan di Sekolah Menengah Kejuruan mengutamakan penyiapan siswa di dalam memasuki dunia industri atau dunia kerja. Keterampilan yang dimiliki siswa, merupakan hasil dari pembelajaran di sekolah maupun di industri. Model pembelajaran sangatlah berpengaruh terhadap keaktifan dan hasil belajar dari siswa itu sendiri, dimana model pembelajaran yang monoton diterapkan mengakibatkan siswa menjadi bosan dalam mengikuti proses belajar mengajar. Hal ini tentu dapat mempengaruhi keaktifan dan hasil belajar siswa itu sendiri.

Arends dalam Suprijono (2009:46) menyatakan model pembelajaran mengarah pada pendekatan yang digunakan guru dan tujuan pembelajaran dari pembelajaran, tahapan dalam kegiatan pembelajaran, lingkungannya dan pengelolaan kelas. Joyce \& Weil (dalam Isjoni, 2013: 50) menyatakan model pembelajaran adalah sesuatu yang sudah direncanakan sebelumnya dan digunakan untuk menyusun kurikulum, mengatur materi pelajaran, memberi petunjuk kepada guru untuk menyampaikan materi pelajaran. Sedangkan Istarani (2011:1) menyatakan model pembelajaran adalah keseluruhan rangkaian dari penyajian materi yang meliputi aspek-aspek pembelajaran dari sebelum, sedang dan sesudah pembelajaran dilakukan oleh guru dengan menggunakan segala fasilitas yang digunakan secara langsung ataupun tidak di dalam proses pembelajaran.

Maka dari itu perlunya seorang guru yang pintar mengelola kelas, terutama pada pemilihan model pembelajaran. Seperti contohnya model pembelajaran kooperatif, Menurut Isjoni (2013:15) pembelajaran kooperatif yaitu dimana siswa di belajarkan secara berkelompok dengan anggota kelompok 4 sampai 6 orang secara kolaboratif dalam proses pembelajaran. Menurut Sanjaya (2008:241) menyatakan bahwa pembelajaran cooperative adalah kegiatan belajar yang dilakukan oleh siswa dalam kelompok tertentu untuk mencapai tujuan tertentu yang telah dirumuskan. Model pembelajaran kooperatif di dalam proses belajarnya siswa di bentuk kedalam kelompok sehingga suasana belajar menjadi lebih kondusif, siswa lebih mudah dalam memahami materi dan semangat dalam melaksanakan tugas belajarnya sehingga dapat meningkatkan keaktifan dan hasil belajarnya. Keaktifan siswa didalam proses pembelajaran merupakan keadaan siswa dimana dirinya aktif dalam proses pembelajaran. Menurut Sudjana (2005 : 72) keaktifan belajar siswa dapat dilihat dari keterlibatan siswa pada 
proses pembelajaran, keterlibatan dalam memecahkan masalah, bertanya kepada teman atau guru jika belum memahami materi yang di jelaskan, berusaha mencari informasi untuk memecahkan masalah, melatih diri dalam memecahkan masalah atau soal yang diberikan. Sardiman (2001 : 98) menyatakan keaktifan belajar merupakan kegiatan yang bersifat pada fisik maupun mental siswa, yaitu berbuat dan berfikir sebagai sesuatu kaitan yang sangat erat. Keaktifan belajar siswa merupakan upaya siswa dalam memperoleh pengalaman belajar sehingga nantinya berpengaruh terhadap hasil belajar siswa.

Dalam hal ini, keaktifan belajar siswa dapat dilihat dari cara siswa berinteraksi dengan teman maupun dengan guru yang mengajar saat proses pembelajaran berlangsung dimana kempampuan siswa saat mengerjakan tugas yang diberikan maupun dalam mengerjakan ujian. Menurut Moh. Uzer Usman (2006:21) mengajar adalah menimbang kegiatan siswa sehingga siswa mau belajar, keaktifan belajar sangatlah penting karena siswalah yang berperan aktif dalam proses pembelajaran. Kemudian hasil belajar menurut Sudjana, (2005:22) hasil belajar adalah kemampuan yang dimiliki siswa setelah menerima pengalaman belajarnya. Menurut Bloom (Suprijono, 2009:6-7) Definisi hasil belajar mencakup kemampuan kognitif, afektif, dan psikomotorik. Hasil belajar siswa merupakan prestasi yang dicapai siswa dalam kegiatan belajar yang dia ikuti dengan membawa perubahan tingkah laku siswa itu sendiri.

Berdasarkan data yang diperoleh dari SMK Negeri 1 Denpasar, pembelajaran yang terlaksana dengan menggunakan model pembelajaran Problem Based Learning (PBL). Menurut Kamdi (2007:77) menyatakan, model pembelajaran Problem Based Learning (PBL) merupakan model pembelajaran yang melibatkan siswa dalam proses memecahkan masalah dan melalui suatu tahapan berupa metode agar siswa mampu mempelajari materi yang berkaitan dengan masalah dan memiliki kemampuan dalam memecahkan suatu masalah. Model pembelajaran ini, dimana pembelajaran dilandaskan tentang suatu masalah yang menuntut agar siswa mendapat pengetahuan yang menjadikan mereka mahir dalam memecahkan suatu masalah. Namun, model ini kurang cocok untuk materi yang akan disampaikan. Pada prakteknya, peran aktif dari siswa dalam pembelajaran itu kurang, hanya saja siswa yang memiliki minat atau siswa yang memiliki kepercayaan bahwa masalah tersebut bisa dia pecahkan yang terlihat lebih aktif dalam pembelajaran ini, jika mereka mempunyai kepercayaan bahwa masalah yang dipelajari sulit untuk mereka pecahkan, maka mereka merasa tidak tertarik untuk mencobanya. Tanpa pemahaman terlebih dahulu mengenai materi, mereka akan belajar dengan apa yang ingin mereka pelajari sehingga hal tersebut mempengaruhi keaktifan dan hasil belajar siswa itu sendiri.

Dari data yang terkumpul melalui proses observasi bahwa KKM mata pelajaran pekerjaan dasar otomotif adalah 75,00. Penerapan model pembelajaran yang monoton menyebabkan siswa merasa jenuh dalam proses pembelajaran. Pada saat guru memberi masalah yang akan dipecahkan oleh kelompok siswa, sebagian siswa hanya diam dan sebagian siswa tidak mempunyai semangat dalam memecahkan masalah yang di berikan oleh guru. Hanya sebagian siswa yang memiliki kemampuan secara akademik yang lebih tinggi yang aktif dalam pembelajaran. Kurangnya keaktifan belajar siswa dapat berhimbas pada hasil belajar siswa itu sendiri. Salah satunya langkah untuk meningkatkan keaktifan dan hasil belajar siswa tersebut dengan menggunakan model pembelajaran yang sesuai, karena tiap siswa mempunyai karakteristik, sifat dan kemampuan yang berbeda. Sehingga diperlukannya pembelajaran yang menarik minat siswa untuk lebih aktif di dalam proses belajar mengajar. Salah satunya dengan menggunakan model pembelajaran kooperatif tipe Team Game Tournament (TGT). Berbeda dengan model pembelajaran kooperatif yang lainnya seperti STAD, Jigsaw dan GI. Team Game Toumament ini tidak hanya semata mata siswa dibentuk 
kedalam kelompok saja, melainkan berisikan game dan tournament akademik sehingga seluruh siswa tanpa terkecuali akan berlomba lomba mengumpulkan point untuk kelompoknya.

Menurut Slavin (2015:163) Team Game Tournament (TGT) merupakan turnamen akademik, dan berisikan dengan kuis-kuis dan sistem skor kemajuan individu, di mana para siswa berlomba sebagai wakil tim mereka dengan anggota tim lain yang kinerja akademik sebelumnya setara seperti mereka. Team Game Tournament (TGT) adalah model pembelajaran kooperatif dimana siswa dibentuk dalam kelompok untuk saling membantu di dalam memahami materi pelajaran dan mengerjakan tugas kelompok dan dipadu dengan kompetensi antar anggota dalam bentuk permainan. Model pembelajaran Kooperatif Tipe Team Game Tournament (TGT) memiliki keunggulan yaitu menurut Shoimin (2014:207) menyatakan model pembelajaran Team Game Tournament (TGT) tidak hanya membuat siswa yang memiliki kemampuan akademis tinggi dari temannya akan lebih terlihat dalam pembelajaran ini, tetapi siswa yang memiliki kemampuan akademis rendah juga akan aktif dan mempunyai tanggung jawab pada kelompoknya. Model pembelajaran Team Game Tournament (TGT), akan menumbuhkan rasa kebersamaan, saling menghargai antara anggota kelompoknya. Model pembelajaran Team Game Tournament (TGT), membuat siswa bersemangat pada saat mengikuti proses pembelajaran, hal ini disebabkan karena diakhir materi, guru memberikan sebuah penghargaan pada kelompok terbaik. Model pembelajaran Team Game Tournament (TGT) ini membuat siswa bersemangat dalam mengikuti proses belajar karena ada kegiatan permainan berupa turnamen akademik. Penerapan model pembelajaran Kooperatif Tipe Team Game Tournament (TGT) diharapkan dapat memberikan makna dan kesan positif kepada siswa. Dengan harapan siswa akan termotivasi agar lebih aktif secara maksimal dalam mengikuti proses pembelajaran.

\section{METODE}

Metode yang digunakan penelitian ini adalah penelitian eksperimen. Gay (dalam Emzir, 2012: 64) menyatakan penelitian eksperimen adalah metode penelitian yang dapat menguji dengan benar hipotesis yang menyangkut hubungan sebab akibat. Rancangan ini dipilih karena sesuai dengan tujuan penelitian, yaitu mengetahui bagaimana keaktifan dan hasil belajar siswa terhadap pembelajaran Pekerjaan Dasar Otomotif menggunakan model pembelajaran Kooperatif tipe Team Game Tournament (TGT) di kelas X TKRO SMK Negeri 1 Denpasar. (Wendra, 2016:32) menyatakan rancangan penelitian merupakan strategi untuk mengatur gambaran penelitian sehingga peneliti mendapatkan data yang valid sesuai dengan karakteristik variabel dan tujuan penelitian yang diharapkan peneliti. Rancangan penelitian ini menggunakan desain MANOVA. Teknik pengambilan sampel pada penelitian ini menggunakan teknik "random sampling" atau sampel yang diambil secara acak. Menurut Sugiyono (2004 :73) sampel penelitan adalah sebagian dari jumlah dan karakteristik yang di miliki oleh populasi. Dari kedua kelas X TKRO di SMK Negeri 1 Denpasar, dilihat dari nilai rata-rata hasil ulangan akhir semester sebelumnya yang diberikan oleh guru pengajar yaitu pada kelas X TKRO 1 adalah 76,53 dan kelas X TKRO 2 adalah 75,55, hal ini bisa dikatakan setara. Untuk memilih kelompok eksperimen dan kelompok kontrol dilakukan pengundian terhadap kedua kelas tersebut.

Berdasarkan pengundian, didapatkan kelas X TKRO 1 sebagai kelas eksperimen dan kelas $X$ TKRO 2 sebagai kelas kontrol. Pada kelas eksperimen diberikan pembelajaran menggunakan model pembelajaran Kooperatif Tipe Team Game Tournament (TGT) dan kelas kontrol diberikan pembelajaran dengan model konvensional (Problem Based Learning).

Metode pengumpulan data adalah cara-cara yang digunakan oleh peneliti untuk mengumpulkan data. Dalam penelitian ini metode pengumpulan data dilakukan untuk mendapat data yang diinginkan, data yang dicari adalah data yang dapat digunakan untuk 
menjawab permasalahan yang dikaji dalam penelitian. Dalam suatu penelitian instrument pengumpulan data yang digunakan berupa pedoman observasi, dokumentasi, teknik tes. Observasi merupakan pengamatan dan pencatatan secara langsung terhadap gejala yang terlihat pada objek penelitian. Observasi dilakukan oleh peneliti dengan cara pengamatan dan pencatatan mengenai pelaksanaan pembelajaran dikelas dengan menggunakan model pembelajaran. Dalam melaksanakan dokumentasi, peneliti menyelidiki objek tertulis seperti buku-buku, majalah, dokumen, peraturan, notulen rapat dan catatan harian dan lain - lain. Teknik tes adalah suatu bentuk teknik yang berupa pentanyaan-pertanyaan yang harus dijawab sesuai dengan petunjuk untuk menentukan tinggi rendahnya skor dalam bentuk kuantitatif

\section{HASIL DAN PEMBAHASAN}

Data yang terkumpul dalam penelitian ini adalah data keaktifan dan hasil belajar pekerjaan dasar otomotif. Pengumpulan data yang digunakan berupa pedoman observasi, dokumentasi, teknik tes. Metode teknik tes digunakan untuk mendapatkan hasil dari keaktifan dan hasil belajar pekerjaan dasar otomotif yang akan di berikan pada akhir penelitian. Tes keaktifan belajar berbentuk kuisioner berjumlah 20 butir dan tes hasil belajar berupa soal pilihan ganda berjumlah 20 butir.

Teknik analisis data yang digunakan adalah analisis statistik deskriftif dan inferensial. Pada analisis statistik deskriftif yaitu menghitung nilai rata-rata atau mean, median, modus, standar deviasi dan varians. Data penelitian ini di sajikan dalam bentuk Kurva Polygon. Pada analisis statistik inferensial, digunakan teknik untuk menguji hipotesis yaitu MANOVA. Sebelum di lakukannya uji hipotesis, syarat yang harus dipenuhi yaitu data harus berdistribusi normal dengan melalui uji normalitas sebaran data, data harus bersifat homogen dengan melalui uji homogenitas.

Rangkuman hasil analisis statistik deskriptif kelompok eskperimen dan kelompok kontrol di tampilkan pada tabel berikut.

Tabel. 1 Rangkuman statistik deskriptif variabel penelitian

\begin{tabular}{lllll}
\hline \multirow{2}{*}{ Statistik } & \multicolumn{2}{l}{ Keaktifan } & \multicolumn{2}{l}{ Belajar } \\
\cline { 2 - 5 } & Eks & Kon & Eks & Kon \\
\hline Mean & 82,25 & 73,28 & 76,81 & 63,47 \\
Median & 83,00 & 74,00 & 77,50 & 62,50 \\
Modus & 83,00 & 75,00 & 80,00 & 65,00 \\
Standar & 8,388 & 7,221 & 10,701 & 13,407 \\
$\begin{array}{l}\text { Deviasi } \\
\text { Varians }\end{array}$ & 70,364 & 52,149 & 114,504 & 179,742 \\
$\begin{array}{l}\text { Skor } \\
\text { Minimum }\end{array}$ & 66 & 58 & 60 & 45 \\
\hline
\end{tabular}




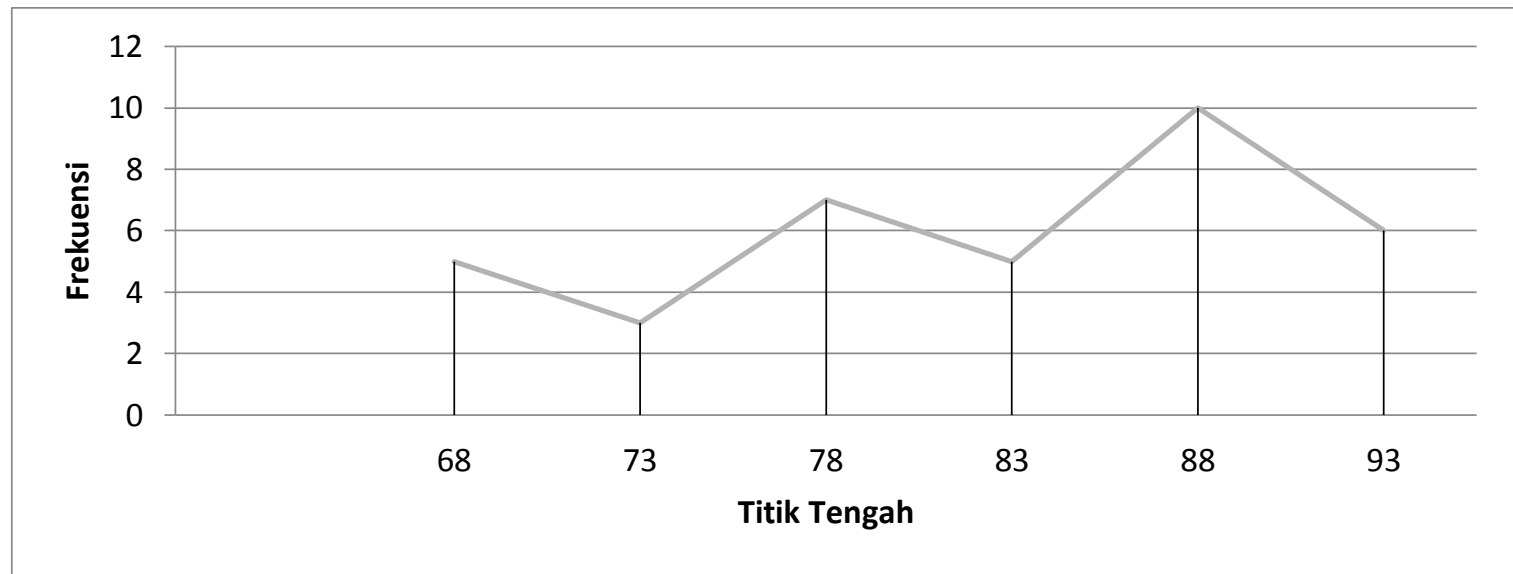

Gambar 1. Kurva Polygon Keaktifan Belajar Pekerjaan Dasar Otomotif Kelas Eksperimen.

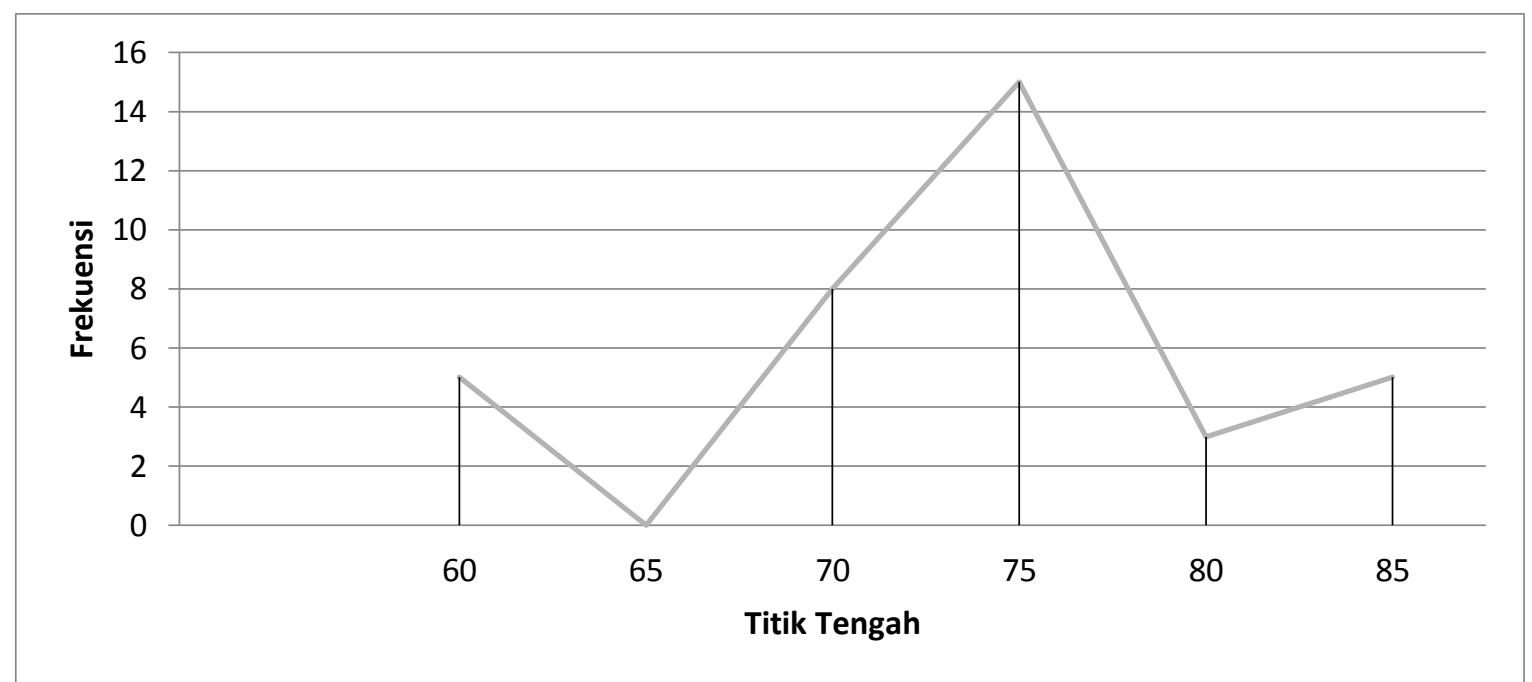

Gambar 2. Kurva Polygon Keaktifan Belajar Pekerjaan Dasar Otomotif Kelas Kontrol.

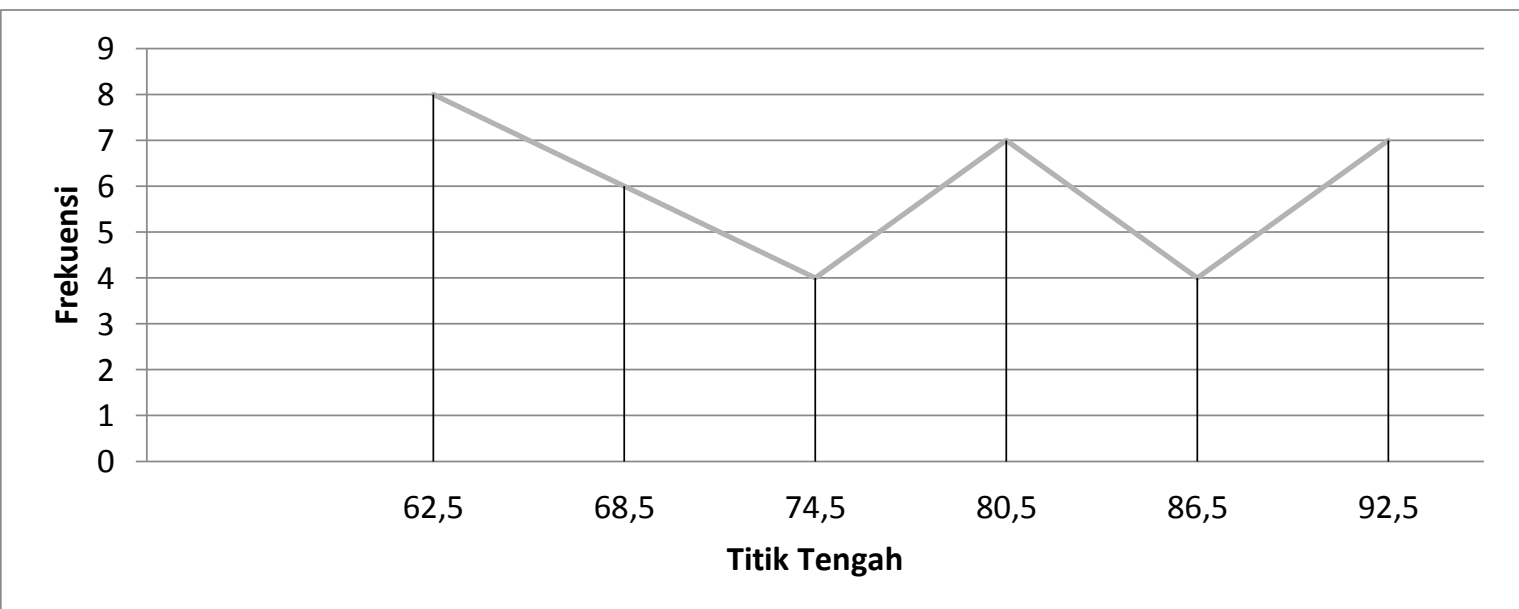

Gambar 3. Kurva Polygon Hasil Belajar Pekerjaan Dasar Otomotif Kelas Eksperimen. 


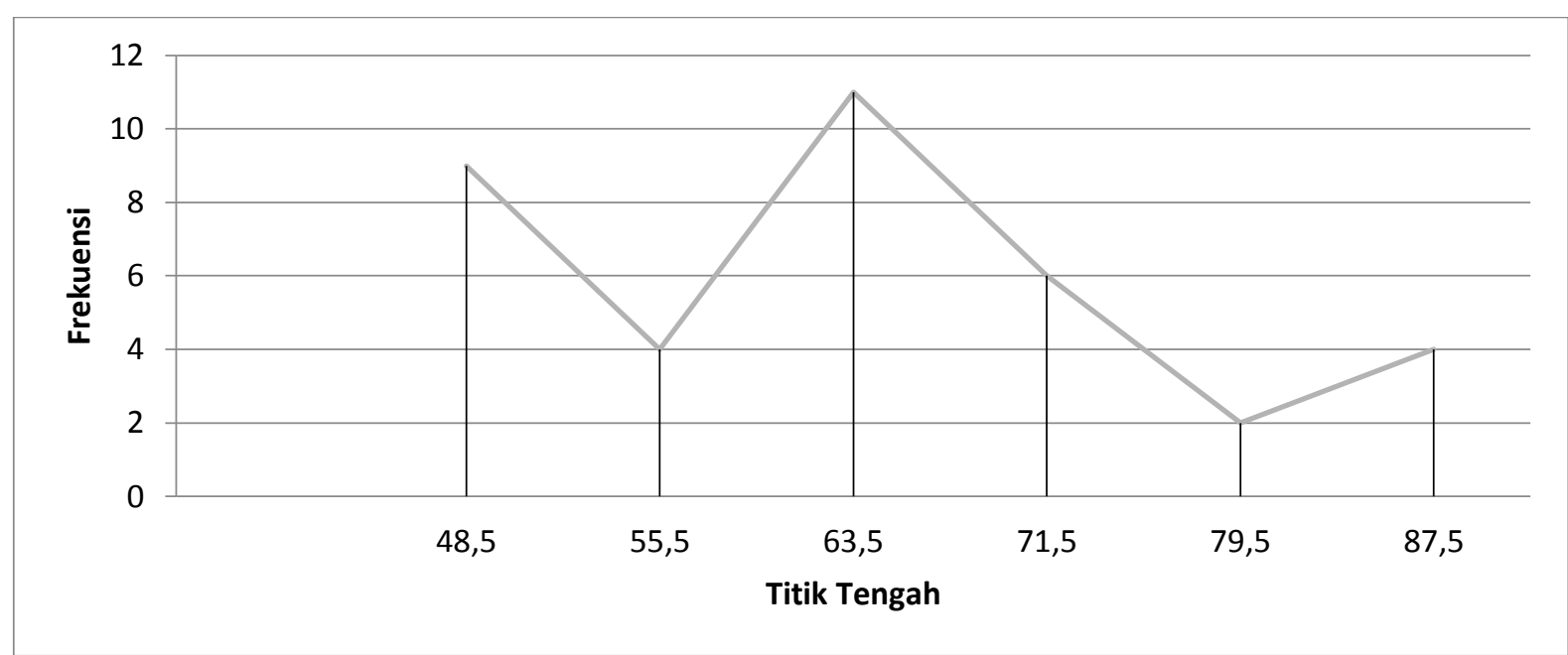

Gambar 4. Kurva Polygon Hasil Belajar Pekerjaan Dasar Otomotif Kelas Kontrol.

Sebelum melakukan analisis data, maka terlebih dahulu dilakukan uji normalitas sebaran data, uji homogenitas. Uji normalitas diakukan dengan menggunakan Kolmogorof-Smirnov dan Shapiro-Wilk dengan bantuan SPSS 24 for windows. Hasil dari uji normalitas menyatakan bahwa (1) keseluruhan nilai signifikan dari Kolmogorof-Smirnov dan Shapiro-Wilk lebih besar dari 0,05. Maka dari itu dapat disimpulkan bahwa data keaktifan belajar pekerjaan dasar otomotif kelompok eksperimen dan kontrol berdistribusi normal, (2) keseluruhan nilai signifikan dari Kolmogorof-Smirnov dan Shapiro-Wilk lebih besar dari 0,05. Maka dari itu dapat disimpulkan bahwa data hasil belajar pekerjaan dasar otomotif kelompok eksperimen dan kontrol berdistribusi normal.

Pengujian hipotesis menggunakan analisis MANOVA dengan bantuan SPSS 24 for windows. Hipotesis menyatakan bahwa (1) Terdapat perbedaan keaktifan belajar pada siswa kelas X TKRO SMK Negeri 1 Denpasar antara kelompok siswa yang mengikuti model pembelajaran kooperatif tipe Team Game Tournament (TGT) dengan kelompok siswa yang mengikuti model pembelajaran konvensional. Berdasarkan data analisis dengan bantuan SPSS24 for windows, diperoleh nilai $\mathrm{F}$ sebesar 23,655, $\mathrm{df}=1$, dan Sig $=0,00$. Ini berarti signifikansi lebih kecil dari 0,05 . Dengan demikian hipotesis nol $\left(\mathrm{H}_{0}\right)$ ditolak dan hipotesis alternatif $\left(\mathrm{H}_{1}\right)$ yang menyatakan terdapat perbedaan keaktifan belajar pada siswa kelas $\mathrm{X}$ TKRO SMK Negeri 1 Denpasar antara kelompok siswa yang mengikuti model pembelajaran kooperatif tipe Team Game Tournament (TGT) dengan kelompok siswa yang mengikuti model pembelajaran konvensional. (2) Terdapat perbedaan hasil belajar pada siswa kelas X TKRO SMK Negeri 1 Denpasar antara kelompok siswa yang mengikuti model pembelajaran kooperatif tipe Team Game Tournament (TGT) dengan kelompok siswa yang mengikuti model pembelajaran konvensional. Berdasarkan data analisis dengan bantuan SPSS24 for windows, diperoleh nilai $\mathrm{F}$ sebesar 21,751 df $=1$ dan sig = 0,000. Ini berarti signifikansi lebih kecil dari 0,05 . Dengan demikian hipotesis nol $\left(\mathrm{H}_{0}\right)$ ditolak dan hipotesis alternatif $\left(\mathrm{H}_{1}\right)$ yang menyatakan terdapat perbedaan hasil belajar pada siswa kelas X TKRO SMK Negeri 1 Denpasar antara kelompok siswa yang mengikuti model pembelajaran kooperatif tipe Team Game Tournament (TGT) dengan kelompok siswa yang mengikuti model pembelajaran konvensional. (3) Terdapat perbedaan keaktifan hasil belajar pada siswa kelas X TKRO SMK Negeri 1 Denpasar antara kelompok siswa yang mengikuti model pembelajaran kooperatif tipe Team Game Tournament (TGT) dengan kelompok siswa yang mengikuti model pembelajaran konvensional. Berdasarkan data analisis dengan bantuan SPSS 24 for windows, diperoleh harga $\mathrm{p}=0,00$ yaitu lebih kecil dari 0,05 pada nilai Pillae Trace, Wilk Lambda, 
Hotelling's Trace, Roy's Largest Root. Ini berarti hipotesis nol $\left(\mathrm{H}_{0}\right)$ ditolak dan hipotesis alternative $\left(\mathrm{H}_{1}\right)$ diterima.

Berdasarkan deskripsi data hasil penelitian, (1) kelompok siswa yang mengikuti pembelajaran kooperatif tipe Team Game Tournament (TGT) yaitu memiliki keaktifan belajar yang lebih tinggi dari pada siswa yang mengikuti pembelajaran konvensional. Rata-rata skor keaktifan belajar yang mengikuti pembelajaran kooperatif tipe Team Game Tournament (TGT) adalah 82,25 hal ini di dasarkan pada rata-rata skor keaktifan belajar pekerjaan dasar otomotif. Rata-rata skor keaktifan belajar yang mengikuti pembelajaran konvensional adalah 73,28 hal ini di dasarkan pada rata-rata skor keaktifan belajar pekerjaan dasar otomotif, (2) kelompok siswa yang mengikuti pembelajaran kooperatif tipe Team Game Tournament (TGT) yaitu memiliki hasil belajar yang lebih tinggi dari pada siswa yang mengikuti pembelajaran konvensional. Rata-rata skor hasil belajar yang mengikuti pembelajaran kooperatif tipe Team Game Tournament (TGT) adalah 76,81 hal ini di dasarkan pada rata-rata skor keaktifan belajar pekerjaan dasar otomotif. Rata-rata skor hasil belajar yang mengikuti pembelajaran konvensional adalah 63,47 hal ini di dasarkan pada rata-rata skor keaktifan belajar pekerjaan dasar otomotif,

Setelah data diolah dengan uji statistik deskriptif, selanjutnya diolah dengan menggunakan uji MANOVA terhadap hipotesis penelitian yang diajukan menunjukan bahwa (1) Terdapat perbedaan yang signifikan data keaktifan belajar pada siswa kelas X TKRO SMK Negeri 1 Denpasar antara kelompok siswa yang mengikuti model pembelajaran kooperatif tipe Team Game Tournament (TGT) dengan kelompok siswa yang mengikuti model pembelajaran konvensional. Dengan nilai F sebesar 23,655, $\mathrm{df}=1$, dan $\mathrm{Sig}=0,00$. Dengan demikian hipotesis nol $\left(\mathrm{H}_{0}\right)$ ditolak dan hipotesis alternatif $\left(\mathrm{H}_{1}\right)$ yang menyatakan terdapat perbedaan keaktifan belajar pada siswa kelas X TKRO SMK Negeri 1 Denpasar antara kelompok siswa yang mengikuti model pembelajaran kooperatif tipe Team Game Tournament (TGT) dengan kelompok siswa yang mengikuti model pembelajaran konvensional, diterima , (2) Terdapat perbedaan hasil belajar pada siswa kelas X TKRO SMK Negeri 1 Denpasar antara kelompok siswa yang mengikuti model pembelajaran kooperatif tipe Team Game Tournament (TGT) dengan kelompok siswa yang mengikuti model pembelajaran konvensional. Dengan nilai F sebesar 21,751 df = 1 dan sig = 0,000. Ini berarti signifikansi lebih kecil dari 0,05. Dengan demikian hipotesis nol $\left(\mathrm{H}_{0}\right)$ ditolak dan hipotesis alternatif $\left(\mathrm{H}_{1}\right)$ yang menyatakan terdapat perbedaan hasil belajar pada siswa kelas X TKRO SMK Negeri 1 Denpasar antara siswa yang mengikuti model pembelajaran kooperatif tipe Team Game Tournament (TGT) dengan kelompok siswa yang mengikuti model pembelajaran konvensional, diterima. (3) Terdapat perbedaan keaktifan dan hasil belajar pada siswa kelas X TKRO SMK Negeri 1 Denpasar antara kelompok siswa yang mengikuti model pembelajaran kooperatif tipe Team Game Tournament (TGT) dengan kelompok siswa yang mengikuti model pembelajaran konvensional, Dengan nilai harga p lebih kecil dari 0,05 pada nilai Pillae Trace, Wilk Lambda, Hotelling's Trace, Roy's Largest Root. Ini berarti hipotesis nol $\left(\mathrm{H}_{0}\right)$ ditolak dan hipotesis alternative $\left(\mathrm{H}_{1}\right)$ yang menyatakan terdapat perbedaan keaktifan dan hasil belajar pada siswa kelas X TKRO SMK Negeri 1 Denpasar antara kelompok siswa yang mengikuti model pembelajaran kooperatif tipe Team Game Tournament (TGT) dengan kelompok siswa yang mengikuti model pembelajaran konvensional, diterima.

\section{KESIMPULAN DAN SARAN}

Penelitian ini menemukan bahwa berdasarkan pembahasan hasil penelitian tentang pengaruh model pembelajaran kooperatif tipe Team Game Tournament (TGT) tehadap keaktifan dan hasil belajar Pekerjaan Dasar Otomotif siswa kelas X TKRO SMK Negeri 1 Denpasar maka peneliti dapat memberikan kesimpulan (1) Terdapat perbedaan keaktifan belajar yang 
signifikan antara kelompok siswa yang mengikuti model pembelajaran kooperatif tipe Team Game Tournament (TGT) dengan rata-rata 82,25 dan siswa yang mengikuti pembelajaran konvensional dengan rata-rata 73,28. Rata-rata keaktifan belajar siswa yang mengikuti model pembelajaran kooperatif tipe Team Game Tournament (TGT) lebih tinggi dari siswa yang mengikuti pembelajaran konvensional. (2) Terdapat perbedaan hasil belajar yang signifikan antara kelompok siswa yang mengikuti model pembelajaran kooperatif tipe Team Game Tournament (TGT) dengan rata-rata 76,81 dan siswa yang mengikuti pembelajaran konvensional dengan rata-rata 63,47. Rata-rata hasil belajar siswa yang mengikuti model pembelajaran kooperatif tipe Team Game Tournament (TGT) lebih tinggi dari siswa yang mengikuti pembelajaran konvensional. (3) Terdapat perbedaan keaktifan dan hasil belajar Pekerjaan Dasar Otomotif secara simultan antara kelompok siswa yang mengikuti pembelajaran kooperatif tipe Team Game Tournament (TGT) dengan kelompok siswa yang mengikuti pembelajaran konvensional. Keaktifan dan hasil belajar pada kelompok siswa yang mengikuti model pembelajaran kooperatif tipe Team Game Tournament (TGT) lebih tinggi dari kelompok siswa yang mengikuti pembelajaran konvensional.

Berdasarkan penelitian ini, saran yang dapat disampaikan yaitu

1. Bagi sekolah

Dengan model pembelajaran yang lebih efektif untuk mata pelajaran Pekerjaan Dasar Otomotif, maka diharapkan sekolah membuat kebijakan yang dapat meningkatkan mutu pendidikan khususnya pada pelajaran Pekerjaan Dasar Otomotif sehingga mencapai tujuan pendidikan yang lebih maju.

2. Bagi Guru

Dengan adanya bermacam model pembelajaran, diharapkan guru menggunakan model pembelajaran yang tepat untuk materi yang akan disampaikan sehingga mendorong siswa lebih aktif dalam proses belajar.

3. Bagi Siswa

Penerapan model pembelajaran kooperatif tipe Team Game Tournament (TGT), diharapkan mampu mendorong siswa menjadi lebih aktif dan bersemangat dalam proses belajar

4. Bagi Peneliti

Dengan menerapkan model pembelajaran kooperatif tipe Team Game Tournament (TGT), dapat menambah pemahaman dan pengalaman bagi peneliti sehingga dapat menyempurnakannya di masa mendatang.

\section{DAFTAR RUJUKAN}

A.M. Sardiman. 2001. Interaksi dan motivasi belajar mengajar. Jakarta : Raja Grafindo Persada.

Emzir. 2012. Metodelogi penelitian pendidikan kuantitatif dan kualitatif. Bandung : Rajagrafindo Persada.

Isjoni. 2013. Cooperative learning efektivitas pembelajaran kelompok. Bandung : Alfabeta.

Istarani. 2011. Model pembelajaran inovatif. Medan : Media Persada.

Kamdi. 2007. Strategi pembelajaran. Bandung : PT Remaja Rosdakarya.

Moh. Uzer Usman. 2006. Menjadi guru profesional. Bandung : PT. Mancama Jaya Cemerlang 
Sanjaya, Wina. 2008. Perencanaan dan desain sistem pembelajaran. Jakarta : Kencana Prenada Media Group.

Shoimin, Aris. 2014. Model pembelajaran inovatif dalam kurikulum 2013. Yogyakarta : ArRuzz Media. Vol. 203.

Slavin, Robert E. 2015. Cooperative learning: Teori, riset dan praktik. Bandung : Nusa Media. Vol. 163.

Sudjana, Nana. 2005. Dasar-Dasar Proses Belajar Mengajar. Bandung : Sinar Baru Algensindo.

Sugiyono. 2004. Metodologi penelitian. Bandung : Alfabeta.

Suprijono, Agus. 2009. Cooperative learning ; Teori dan aplikasi PAIKEM Yogyakarta : Pustaka Pelajar.

Wendra. 2016. Penulis karya ilmiah. Singaraja : Universitas Pendidikan Ganesha. 